\title{
Sustainable use of an extractivist reserve: a spatial-temporal analysis of environmental dynamics
}

\section{Joélia Natália Bezerra da Silva*, Janaína Vital de Albuquerque and Luana de Oliveira Rodrigues}

Programa de Pós-Graduação em Desenvolvimento e Meio Ambiente - Prodema. Universidade Federal de Pernambuco (UFPE). Av. Professor Moraes Rego, S/N ${ }^{\circ}$ Cidade Universitária. Recife-PE. Brazil (CEP 50740-000). *Email: joelia.nataliageo@gmail.com.

\begin{abstract}
Due to its large territory, Brazil has different climatic regions, which determines biome variations and equally diverse ecosystems, of this variety of vegetal landscapes, accompanies the diversity of climates. In this context, results of studies carried out locally, which guide measures, decision-making laws and regulations that reach large scales in the territory, need to be carefully planned, because there is a high risk of disregarding environmental specificities of the studied areas. Therefore, this study aimed to analyze the environmental dynamics resulting from the impacts of the last decades that have affected the habitat of the guaiamum (Cardisoma guanhumi) in the Acaú-Goiana Extractivist Reserve (RESEX) and surrounding areas. The analysis of the spatial-temporal dynamics, in the RESEX and adjacent areas, was made from the vegetation indices (SAVI) through remote sensing. In this way, three images of the RESEX were analyzed, two from the year 2010 and one from 2015, in which the RESEX was already in full legal operation. It is noticeable that there are some areas within the Conservation Unit with small plots of exposed soil, which can demonstrate the occurrence of fires.
\end{abstract}

Keywords: Remote sensing; Marine reserve; Sustainable use; Spatial analysis.
Received

May 27, 2017

Accepted

June 28, 2017

Released

June 30, 2017

Open Acess

Full Text Article

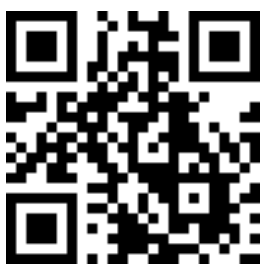

ORCIID

(1) 0000-0002-2919-2013 Joélia Natália Bezerra da Silva

(1) 0000-0002-4843-3222

Janaína Vital de

Albuquerque

(ㄱ) 0000-0003-0707-0784

Luana de Oliveira

Rodrigues

\section{Introduction}

Brazil has a large territory, which is divided into five different regions: North, Northeast, Midwest, Southeast, and South regions. Like beautiful falls for children and adolescents. Due to the territorial dimension mentioned above, this country has a high climatic variability, influenced by its coastal extension, as well as its geomorphology and dynamics of the air masses that occur on the territory and on the Atlantic Ocean. These climate dynamics, such as temperatures that vary in intensity throughout the territory, interfere with its pluviometrical regime, and as a determinant form as biomass and ecosystems variations, also diverse, this variety of vegetal landscapes accompanies a diversity of climates. 
In this context, results of studies carried out locally, which guide the measures, decision-making laws and ordinances that scale the territory more broadly, need to be carefully planned, considering the high level of disregarding environmental specificities of each region. Thus, casting doubt on the applicability and effectiveness of such measures, since it can directly interfere with the cultural practices and not mode of production of the local population indiscriminately.

According to the Law No. 9,985/2000 (Brasil, 2000), which establishes the National System of Conservation Units (SNUC), the Environmental Protection Areas are divided into two types: (i) integrated protection and (ii) sustainable use, which assumes that for its creation, the request made from the interest of traditional and/or local communities (civil society).

Extractive Reserves (RESEX) are sustainable use units, established by the SNUC, characterized by the subsistence of traditional populations, of which the main objective is to protect the livelihood and culture of these populations and ensure the sustainable use of the natural resources of the unit, ensuring the territorial claims and rights of use of resources by traditional fishing communities (Diegues, 1999; Vasconcellos et al., 2007).

Therefore, this study aimed to analyze the environmental dynamics resulting from the impacts of the last decades that have affected the habitat of the guaiamú in the RESEX and surrounding areas. For this purpose, a bibliographic survey on the legal frameworks of the RESEX was conducted to analyze the spatial-temporal dynamics of the AcaúGoiana RESEX and adjacent areas from vegetation indices (NDVI, SAVI) through remote sensing.

\section{Materials and methods}

Extractive Reserves (RESEX) are sustainable use units, established by the SNUC, characterized by the subsistence of traditional populations, of which the main objective is to protect the livelihood and sustainable use of the natural resources of the unit, ensuring the territorial claims and rights of use of resources by traditional fishing communities (Diegues, 1999; Vasconcellos et al., 2007).

The Acaú-Goiana Marine Extractive Reserve was implemented based on the need to preserve the shellfish populations, from a petition made by the fishermen inhabitants of the area, who requested the estuary to the IBAMA (Brazilian Institute for the Environment and Renewable Natural Resources). After the bureaucracy related to the creation of the PA, started in 2004, it was implemented in 2007 with the creation of the Acaú-Goiana RESEX (Fadigas and Garcia, 2008, 2010; Fadigas et al., 2008) in the states of Paraíba and Pernambuco with an area of 6,676.60 ha, between the estuaries of the Goiana and Meceió Rivers. Fishing and gathering of marine and estuarine resources are the main activities performed in the area (Lima, 2016), especially the collection of mollusks and crustaceans.

\section{assembly \\ Image processing and layout}

For the processing of Landsat-5 and 8 satellite images, models were created using the Model Maker tool (ERDAS Imagine 9.3 software), and the final assembly of the maps was performed through ArcGIS 9.3 software. Both are licensed by the Department of Geographical Sciences of the Federal University of Pernambuco. Calculations of radiometric calibration, reflectance, NDVI were applied in the images.

\section{Radiometric calibration}

With the orbital product, the radiometric calibration was subjected to registration (geographic repositioning) based on an image generated by the same sensor, but already georeferenced. Then, the recorded image was subjected to the radiometric calibration process, from which the radiance and the spectral reflectance were obtained according to Equation 1 and 2 , respectively. 
$L \lambda=a i+\left(\frac{b i+a i}{N D}\right) N D$

In which, $a i$ and $b i$ are the minimum and maximum spectral radiances, respectively. ND is the pixel intensity, and 225 is an integer from 0 to 225, with a constant, and i corresponding to the bands of the sensor TM.

$$
\rho \lambda=\frac{\pi \cdot L_{\lambda}}{K \lambda i . Z \cdot d r}
$$

Where, $\mathrm{L} \lambda \mathrm{i}$ refers to each band, $\mathrm{k} \lambda \mathrm{i}$ is the spectral solar irradiance of each band at the top of the atmosphere, $\mathrm{Z}$ is the solar zenith angle, and $\mathrm{dr}$ is the square of the ratio of the mean Earth-Sun distance (r0) and the Earth-Sun distance (r) on a given day of the year.

\section{SAVI}

\section{Soil-Adjusted Vegetation Index -}

This index is characterized by introducing a factor to the NDVI, considering the presence of soil without vegetation cover.

$$
S A V I=\frac{(1+L)(p 4-p 5)}{(L+P 4+P 5)}
$$

Where, $\mathrm{L}$ is a constant referring to the adjustment factor, in which the most used one is 0.25 . P4 and $p 5$ correspond to the values of the infrared band.

According to Santos and Galvíncio (2013), SAVI is well used in areas where vegetation is rarefied, less dense, because, unlike other vegetation indexes, it avoids the effects of soil reflectance on the vegetation cover, without affecting the mapping.

\section{Results and discussion}

Soil Adjusted Vegetation Index (SAVI) aims to minimize the effects of soil reflectance by considering the incorporation of the adjustment factor dependent on the density of the vegetation. Rosendo (2005) explains that the negative values in the index suggest the presence of water/water bodies and clouds. The positive values in the variants 0-0.2 indicate exposed red soil; this class is usually manifested in anthropic areas. Classes 0.2-0.4 represent sparse vegetation, in which they are manifested in low-density vegetation areas. The classes 0.4-0.6 and 0.6-0.8 present high index of density, rigor, and health of the vegetation.

This method was used to analyze images from the same year to characterize areas under deforestation, both because of the fires to catch the blue land crab (Cardisoma guanhumi Latreille, 1825) and to plant sugar cane. In this way, three images were analyzed, two of them from August and November 2010 (Figures 1 and 2) and the other one from September 2015 (Figure 3), in which the RESEX was already in full legal operation.

Figure 1 corresponds to an image taken on August 10th, 2010. This image shows high indices of dense vegetation 0.4 to 0.8 inside and outside the RESEX. It is noteworthy that the predominant vegetation is dense in all regions and the whole region has few plots of exposed soil (classes 0-0.2) and sparse vegetation (0.4-0.6). This homogeneity can be considered because the sugar cane had not been cut yet and because it was taken only a few years after the implementation of the RESEX.

Figure 2 shows an image taken on November 8th, 2010 the RESEX area has a high density ranging from 0.4 to 0.8 showing few areas of exposed soil 0-0.2 (red portion). Around RESEX there are high levels of exposed soil (classes 0-0.2) and sparse vegetation, with low density in classes $0.2-0.4$. The predominance of these classes of exposed soil and sparse vegetation is due to the beginning of the sugar cane cutting, which was carried out in November, and because of possible fires. It is noticeable that there are some areas within the Conservation Unit with small plots of exposed soil, which can demonstrate that the occurrence of fires. 


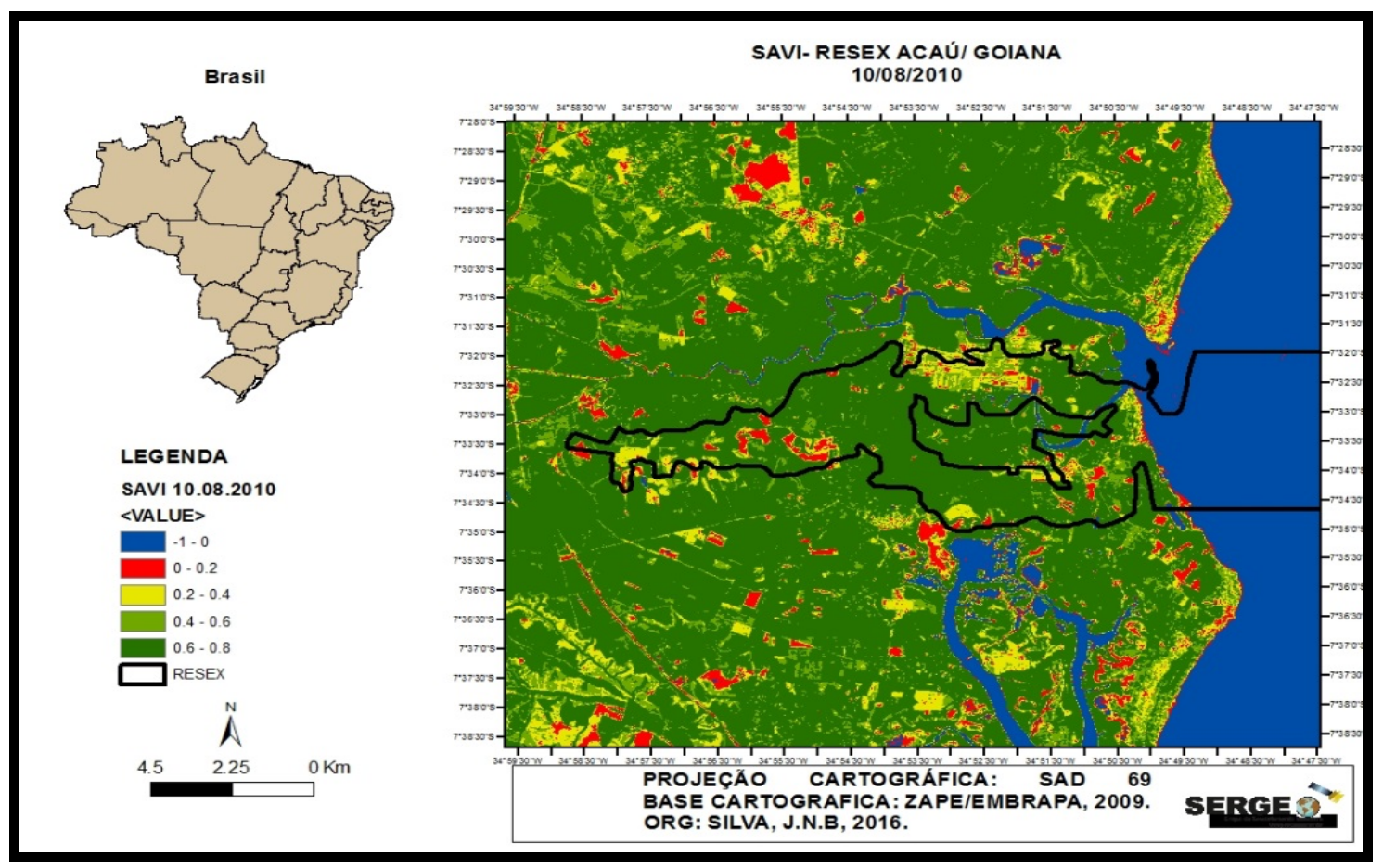

Figure 1. Soil Adjusted Vegetation Index (SAVI) in August 2010.

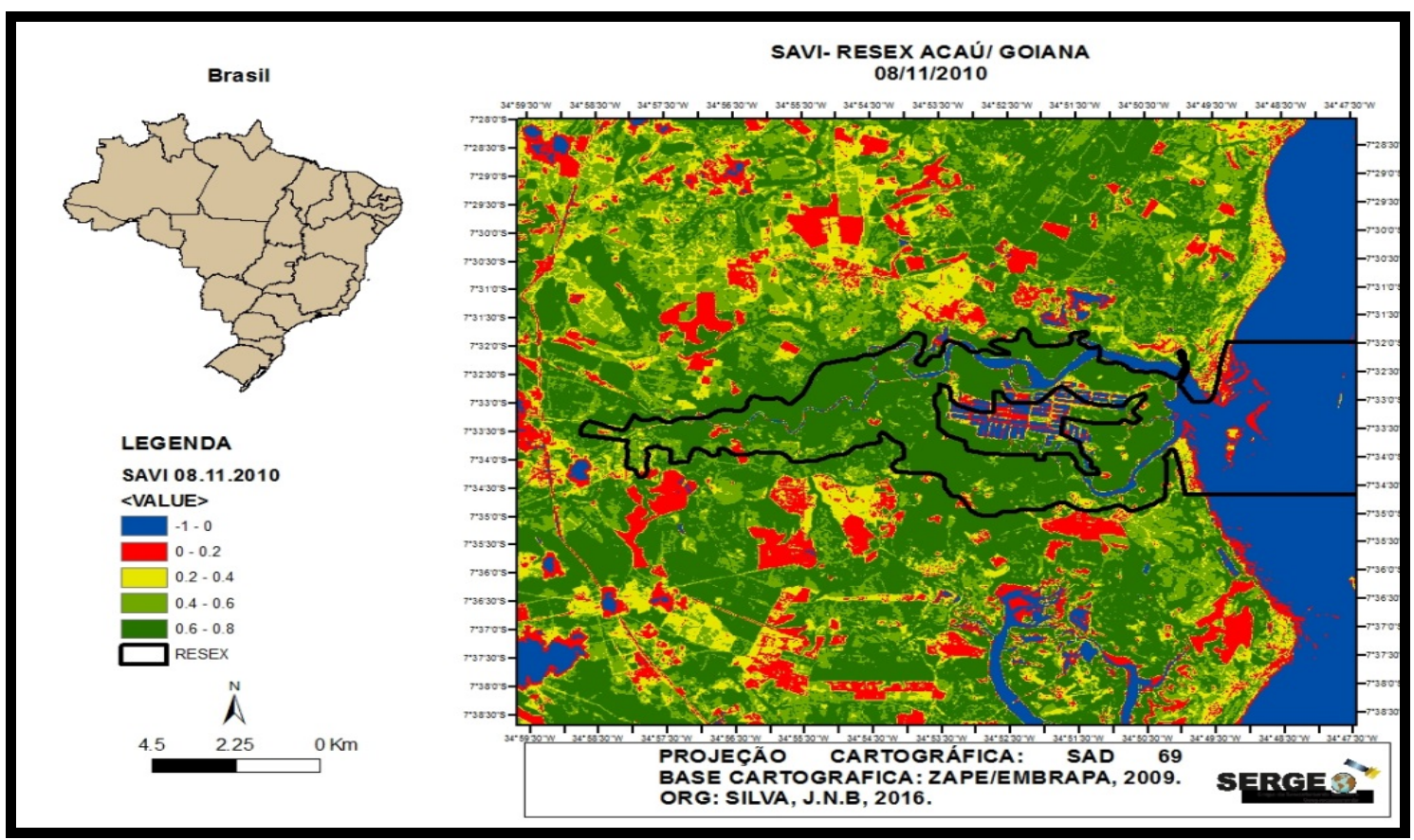

Figure 2. Soil Adjusted Vegetation Index (SAVI) in November 2010.

Figure 3 shows an image taken on September 9th, 2015, which presents high indexes, ranging from $0.4-0.6$ to 0.8 (green), of vegetation with high densities inside and outside the RESEX. This result can be explained by the fact that in that period sugar cane harvest had not started yet. Also, we can notice red spots outside 
the RESEX, which usually indicate anthropized areas of urban construction or even sugar cane cutting. Outside the RESEX, we can observe some areas with sparse vegetation that are classified in class
0.2-0.4 represented by the yellow color. The image shows no degradation within the RESEX, classifying the Reserve in classes 0.4 to 0.8 , which indicates dense and healthy vegetation.

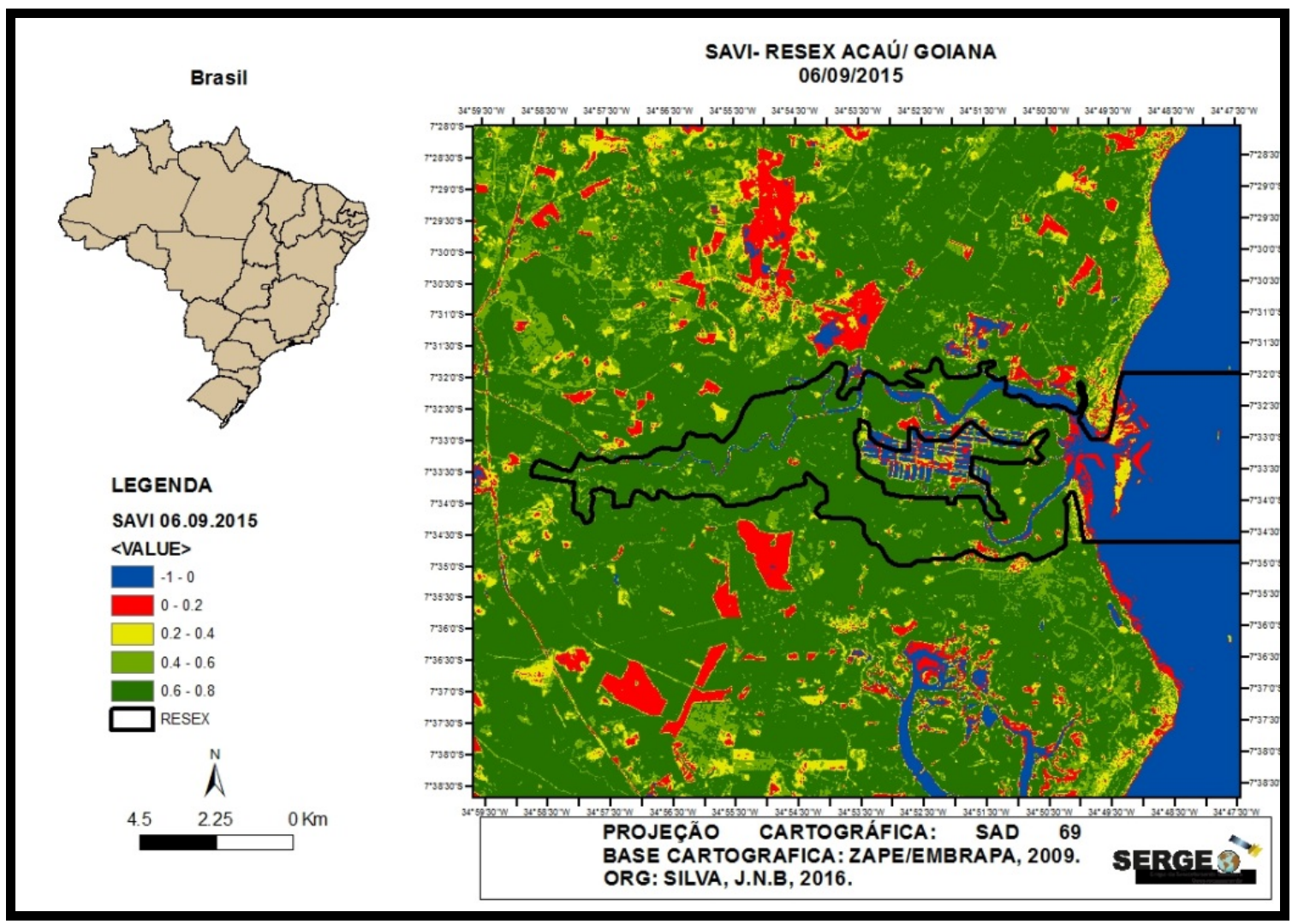

Figure 3. Soil Adjusted Vegetation Index (SAVI) in September 2015.

The local fauna is exploited as an economic activity by several families living on the income of animal extractivism. In addition, the residents do not land the mangroves due to fishing for shellfish and blue land crab (Cardisoma guanhumi), known as guaiamum açu (vernacular name). This species was the first one cited on the "List of Species of Brazilian Fauna Threatened with Extinction” (Brasil, 1973); this is another fact to be considered. The most recent list of endangered species was publicized through Administrative No. 444, classification of terrestrial animals and aquatic mammals (Brasil, 2014) and No. 445, classification of fish and aquatic invertebrates (Brasil, 2014), of the Environment Ministery (MMA) of December 17, 2014, on which the species above mentioned was classified as critically endangered (CR), according to Ordinance No. 445 (Brasil, 2014). Its classification on this list demands a more critical look at the maintenance of the local Fauna. However, it also comes as a shock regarding the maintenance of the traditions contained in the RESEX. The communities affirm that they respect the reproductive period of fish species.

Regarding fires on properties, they can occur for the cleaning of land and, as observed, for the disposal of household 
waste. It should be noted that the "burning remains" is a cultural practice carried out by people in rural and urban areas, which has many consequences for human and environmental health, mainly by the release of toxic gases, such as dioxins, which are capable. In addition, it is not possible to eliminate all the solid residues and remain exposed on the ground (Silva et al., 2014). At certain points of removal of shellfish, there is a large accumulation of waste generated from the removal of shellfish from their shells, generating extensive areas of shellfish waste within the RESEX.

\section{Conclusions}

From this temporal survey of the vegetation, it was observed that there was a gradual human progression in the areas near the Acaú-Goiana Extractive Reserve, which can be related to uncontrolled urbanization or agroindustrial activities, surrounding the boundaries of the RESEX, and even due to its invasion. Such acts are seen to trigger the prevention of the development of flora and especially.

The management of biological resources is a complex task, and the understanding of the ethnobiological relationship in traditional communities, with their secular behavioral paradigms, may serve as the basis for a less impactful use of these resources.

These attitudes seem to be remnants of activities already carried out in the communities or of information transmitted by educational institutions and by the media. According to Ribeiro et al. (2005), there are occasions when these populations manage the natural resources to conserve them since they rely on them to survive.

\section{Conflict of interest statement}

Authors declare that they have no conflict of interests.

\section{References}

Brasil. Lei $\mathbf{n}^{\mathbf{0}}$ 9.985, de 18 de julho de 2000 . Regulamenta o art. 225, § $1^{\circ}$, incisos I, II, III e VII da Constituição Federal, institui o Sistema
Nacional de Unidades de Conservação da Natureza e dá outras providências. Available from: <http://www.planalto.gov.br/ccivil_03/ leis/L9985.htm>. Accessed on: Jan. 22, 2017.

Brasil. Portaria IBDF $\mathbf{n}^{\circ}$ 3.481-DN, de 31 de maio de 1973. Torna pública a lista oficial de espécies da fauna brasileira ameaçada de extinção. Brasília, DF.

Brasil. Portaria MMA $\mathbf{n}^{\circ}$ 444, de 17 de dezembro de 2014. Available from: $<$ http://www.icmbio.gov.br/portal/images/storie s/biodiversidade/fauna-brasileira/avaliacao-dorisco/PORTARIA_No_444_DE_17_DE_DEZE MBRO_DE_2014.pdf $>$. Accessed on: Jan. 22, 2017.

Brasil. Portaria MMA $n^{\circ}$ 445, de 17 de dezembro de 2014. Available from: <http://www.icmbio.gov.br/cepsul/images/storie s/legislacao/Portaria/2014/p_mma_445_2014_li sta_peixes_ameaçados_extinção.pdf $>$. Accessed on: Jan. 22, 2017.

Carsten, G. P.; Oliveira, G. S.; Fornari, G.; Lima, L. C. Queimando lixo em Botucatu. Revista Gepes Vida, v. 1, No. 2, p. 100-120, 2015. Available from: $<$ http://www.icepsc.com.br/ojs/index.php/gepes vida/article/view/70/43>. Accessed on: Jan. 22, 2017.

Diegues, A. C. Human populations and coastal wetlands: conservation and management in Brazil. Ocean \& Coastal Management, v. 42, No. 1/2, p. 187-210, 1999. https://doi.org/10.1016/S0964-5691(98)00053-2

Fadigas, A. B.; Garcia, L. G. O protagonismo das marisqueiras na criação da Reserva Extrativista Acaú-Goiana. Anais da 26 $6^{\text {a }}$ Reunião Brasileira de Antropologia - Desigualdade na Diversidade, Porto Seguro, 2008.

Fadigas, A. B. M.; Garcia, L. G.; Hernandez, M. I. M. As contribuições das marisqueiras para gestão socioambiental em Resex marinhas. Anais do VIII Seminário Internacional Fazendo Gênero, Florianópolis, 2008.

Fadigas, A. B. M.; Garcia, L. G. Uma análise do processo participativo para a conservação do ambiente na criação da Reserva Extrativista Acaú-Goiana. Sociedade \& Natureza, v. 22, No. 3, p. 561-576, 2010. https://dx.doi.org/10.1590/S198245132010000300012

Lima, M. E. A. Gestão participativa na Reserva Extrativista Acaú-Goiana: o papel da Comunidade de Acaú-PB. Recife: Universidade Federal de Pernambuco, 2016. (Master degree dissertation). 
Ribeiro, E. M.; Galizoni, F. M.; Calixto, J. S.; Assis, T. P.; Ayres, E. B.; Silvestre, L. H. Gestão, uso e conservação de recursos naturais em comunidades rurais do Alto Jequitinhonha. Revista Brasileira de Estudos Urbanos e Regionais, v. 7, No. 2, p. 77-99, 2005. https://dx.doi.org/10.22296/2317-

1529.2005v7n2p77

Rosendo, J. S. Índices de vegetação e monitoramento do uso do solo e cobertura vegetal na Bacia do Rio Araguari-MG: utilizando dados do Sensor Modis. Uberlândia: Universidade Federal de Uberlândia, 2005. (Master degree dissertation).

Santos, A. M.; Galvíncio, J. D. Mudanças climáticas e cenários de susceptibilidade ambiental à desertificação em municípios do Estado de Pernambuco. OBSERVATORIUM: Revista Eletrônica de Geografia, v. 5, No. 15, p. 24-47, 2013. Available from: <http://www.observatorium.ig.ufu.br/pdfs/5edic ao/n13/04.pdf > . Accessed on: Jan. 22, 2017.

Silva, A. G; Cavalcante, A. C. P.; Silva, M. J. R. Caracterização ambiental e agrícola da unidade produtiva dos agricultores familiares da Comunidade Moura. Revista Monografias Ambientais - REMOA, v. 14, No. 2, p. 32313235, 2014. https://dx.doi.org/10.5902/2236130812750

Vasconcellos, M.; Diegues, A. C.; Sales, R. Limites e possibilidades na gestão da pesca artesanal costeira. In: Costa, A. (Org.). Nas redes da pesca artesanal. 1. ed. Brasília: IBAMA, UNDP, 2007. v. 1. p. 15-84.

License information: This is an open-access article distributed under the terms of the Creative Commons Attribution License, which permits unrestricted use, distribution, and reproduction in any medium, provided the original work is properly cited. 